\title{
EVALUATION OF THE OPERATION AND MAINTENANCE OF BULK TANKS ON THE TATRA 815 CHASSIS OF FIRE AND RESCUE SERVICE BRIGADES IN THE SOUTH-MORAVIAN REGION
}

\author{
Ladislav JÁNOŠÍK ${ }^{1}$, Ivo DVOŘÁK²
}

Review article

\begin{tabular}{|c|c|}
\hline Abstract: & $\begin{array}{l}\text { This paper is focused on the evaluation of data of the operation of tanker truck syringes } \\
\text { designed for high-volume extinguish on TATRA chassis for the period } 2010-2014 \text {, } \\
\text { which are placed at the Fire and Rescue Service brigades in the South-Moravian Region. } \\
\text { At the beginning of the analysis, statistical data on intervention activities focusing on the } \\
\text { frequency of utilization of vehicles in response and other activities were evaluated. Then, } \\
\text { analyses of kilometric mileage and hour meter reading of machine work in a stand were } \\
\text { carried out. These analyses characterize the traffic load. Subsequently, selected operating } \\
\text { characteristics are calculated and in the end, the results are compared with previous } \\
\text { research of the first-response tanks. }\end{array}$ \\
\hline Keywords: & Tanker truck syringe, operation, disorder, repair, maintenance. \\
\hline
\end{tabular}

\section{Introduction}

The South-Moravian Region has an area of 7.2 thousand $\mathrm{km}^{2}$ and a population of about 1.2 million. In terms of organization of professional fire brigades, the region is divided into 6 regional departments, with a total of 24 fire stations. A group of 24 vehicles of the type of tanker truck syringe was chosen for the analysis of operation and maintenance. The older vehicles on chassis T815 PR $2222356 \times 6.1$ ( 7 vehicles) dominate in a group. The older group consists of three vehicles; their average age is 17.7 years. The remaining 17 vehicles have an average age of 27.5 years. There are also new cars on the chassis T815-731R32 263256 x 6.1 (4 vehicles) represented. The average age of these four vehicles is 2.5 years. The overview of the vehicles in terms of their design, location and data acquisition and reconstruction is given in Tab. 1 .

To an approximate idea of the technique, in the case of older vehicles TATRA 815-2, it is a fire vehicle with a maximal allowable weight of 22.5 tons, with an engine power of $235 \mathrm{~kW}$, and dimensions of $8.51 \times 2.50 \times 3.35 \mathrm{~m}$ (length/width/height). The pump supplies a nominal flow volume of water $321 \mathrm{~min}^{-1}$ at an outlet pressure of $8 \mathrm{MPa}$. The extinguishing volume is characterized by a water tank of 82001 size and a foamer tank 8001 . The average age of this group of vehicles is 26 years.
In the case of newer tanks on the chassis TATRA $815-7$, it is a new generation of vehicles with a permissible weight of 26 tons, with an engine power of $325 \mathrm{~kW}$ and dimensions of $9.10 \times 2.55 \mathrm{x}$ $2.96 \mathrm{~m}$ (length/width/height). The pump supplies a nominal flow volume of water $301 \mathrm{~min}^{-1}$ at an outlet pressure of $10 \mathrm{MPa}$. The extinguishing volume is characterized by a water tank of 90001 size and a foamer tank 5401 . More tactical and technical characteristics of the vehicles can be traced from the manufacturer of fire vehicles (THT, 2015) or they are given e.g. (Monoši, 2013).

To characterize the workload of fire fighting equipment, the number of incidents over the years 2010 to 2014 in the South Moravian Region, where the Fire and Rescue Service brigades were involved, is listed in Tab. 2 (Vonásek, 2011 till 2015). Although the total number of events seen in recent years increased, the tanks-workload is rather decreasing. In summary, during the reporting period, the average share of the number of response of the tanks of the total number of incidents is only $13.4 \%$.

VŠB - Technical University of Ostrava, Faculty of Safety Engineering, Ostrava, Czech Republic, ladislav.janosik@vsb.cz

2 VŠB - Technical University of Ostrava, Faculty of Safety Engineering, Ostrava, Czech Republic, ivo.dvorak.st@vsb.cz 
Tab. 1 Overview of the reporting vehicles

\begin{tabular}{|c|c|c|c|c|c|c|}
\hline Fire station & Designation vehicle & $\begin{array}{c}\text { License } \\
\text { plate }\end{array}$ & $\begin{array}{c}\text { Type of vehicle } \\
\text { chassis }\end{array}$ & The bodybuilder & $\begin{array}{c}\text { Year of } \\
\text { manufacture }\end{array}$ & $\begin{array}{c}\text { Year of } \\
\text { reconstruction }\end{array}$ \\
\hline Blansko-C1 & CAS30/9000/540-S3VH & 9B1 3364 & TATRA 815-7 & WISS s.o.o., Bielsko-Biala & 2013 & \\
\hline Kyjov-P1 & CAS30/9000/540-S3VH & 9B13370 & TATRA 815-7 & WISS s.o.o., Bielsko-Biala & 2013 & \\
\hline Znojmo-C1 & CAS30/9000/540-S3VH & 9B1 3362 & TATRA $815-7$ & WISS s.o.o., Bielsko-Biala & 2013 & \\
\hline Tišnov-P2 & CAS30/9000/600-S3VH & 5B4 3306 & TATRA 815-7 & THT s.r.o, Polička & 2011 & \\
\hline Lidická-C3 & CAS32/8200/800-S3R & BSB 63-63 & TATRA 815-2 & KAROSAn.p., Vysoké Mýto & 1989 & \\
\hline Blansko-C1 & CAS32/8200/800-S3R & BKA 15-02 & TATRA $815-2$ & THT s.r.o, Polička & 1985 & 2001 \\
\hline Hodonín-C1 & CAS32/8200/800-S3R & HO 87-65 & TATRA $815-2$ & THT s.r.o, Polička & 1986 & 1996 \\
\hline Mikulov-P1 & CAS32/8200/800-S3R & BSB 14-93 & TATRA $815-2$ & STROJINVEST n.p., Brno & 1985 & 2012 \\
\hline Vyškov-C1 & CAS32/8200/800-S3R & VY 47-47 & TATRA $815-2$ & KOMET Pečky & 1987 & 2010 \\
\hline Bučovice-P1 & CAS32/8200/800-S3R & VY 76-33 & TATRA $815-2$ & THT s.r.o, Polička & 1996 & \\
\hline BVV-P3 & CAS32/8200/800-S3R & BKA 24-85 & TATRA $815-2$ & KAROSAn.p., Vysoké Mýto & 1989 & \\
\hline Znojmo-C1 & CAS32/8200/800-S3R & ZN 82-04 & TATRA $815-2$ & THT s.r.o, Polička & 1990 & 2000 \\
\hline Hustopeče-P1 & CAS32/8200/800-S3R & BVA $35-40$ & TATRA $815-2$ & THT s.r.o, Polička & 1986 & 2001 \\
\hline Boskovice-P2 & CAS32/8200/800-S3R & BKA 43-97 & TATRA $815-2$ & THT s.r.o, Polička & 1996 & \\
\hline Břeclav-C1 & CAS32/8200/800-S3R & BVA 52-34 & TATRA $815-2$ & KAROSAn.p., Vysoké Mýto & 1990 & \\
\hline Pozořice-P1 & CAS32/8200/800-S3R & ZN 78-73 & TATRA 815-2 & THT s.r.o, Polička & 1989 & 2003 \\
\hline Rosice-P2 & CAS32/8200/800-S3R & BSD 46-43 & TATRA $815-2$ & THT s.r.o, Polička & 1989 & 2002 \\
\hline Tišnov-P2 & CAS32/8200/800-S3R & BKA 26-39 & TATRA $815-2$ & KAROSAn.p., Vysoké Mýto & 1990 & \\
\hline Židlochovice-P1 & CAS32/8200/800-S3R & BSB 26-75 & TATRA $815-2$ & STROJINVEST n.p., Brno & 1986 & 2013 \\
\hline Líšeň-P4 & CAS32/8200/800-S3R & 5B4 3494 & TATRA $815-2$ & THT s.r.o, Polička & 2000 & \\
\hline Hrušovany n.J.-P1 & CAS32/8200/800-S3R & ZN 63-75 & TATRA 815-2 & THT s.r.o, Polička & 1985 & 1999 \\
\hline Veselí n. Mor.-P1 & CAS32/8200/800-S3R & HOA 04-62 & TATRA 815-2 & KOMET Pečky & 1989 & 2009 \\
\hline Ivančice-P1 & CAS32/8200/800-S3R & BIA 07-26 & TATRA 815-2 & KOMET Pečky & 1986 & 2008 \\
\hline Pohořelice-P1 & CAS32/8200/800-S3R & BVA 40-86 & TATRA $815-2$ & KOMET Pečky & 1987 & 2008 \\
\hline
\end{tabular}

Tab. 2 Incident statistics for the years 2010 to 2014 in the South-Moravian Region

\begin{tabular}{|l|c|c|c|c|c|c|c|}
\hline Area Department/Year & $\mathbf{2 0 1 0}$ & $\mathbf{2 0 1 1}$ & $\mathbf{2 0 1 2}$ & $\mathbf{2 0 1 3}$ & $\mathbf{2 0 1 4}$ & $\begin{array}{c}\text { Intervention using } \\
\text { a water tenders }\end{array}$ & Quotient [\%] \\
\hline Blansko & 826 & 731 & 732 & 902 & 990 & 557 & 13 \\
\hline Brno-město & 3516 & 3141 & 3363 & 3760 & 3565 & 1117 & 6 \\
\hline Brno-venkov & 1902 & 2910 & 2189 & 2302 & 2797 & 1775 & 15 \\
\hline Břeclav & 708 & 766 & 765 & 865 & 1200 & 886 & 21 \\
\hline Hodonín & 696 & 662 & 795 & 828 & 915 & 552 & 14 \\
\hline Vyškov & 855 & 767 & 843 & 877 & 1040 & 429 & 10 \\
\hline Znojmo & 797 & 653 & 695 & 776 & 939 & 563 & 15 \\
\hline
\end{tabular}

\section{Materials and Methods}

The Order of Machine Services (Instruction No. 9, 2006) defines the records of the use of fire fighting equipment. Responsible employees of Machinery Service Station have an obligation to monitor the information on the operation and maintenance of vehicles placed at the station. The records of the work of fire fighting equipment, which include the date, purpose of journey, mileage and the final odometer reading, number of hours of work (hours of operation, hour meter reading), refueling and fluids, service activities, costs of operation or repair and the time, the vehicle is taken out of action-capable state, are recorded in the ride-statement. For this purpose, logbooks of vehicles in paper form were previously kept. Since 2010, an electronic information system IKIS II, which forms the central database of vehicles Fire and Rescue Service in the Czech Republic, has been used for this purpose. The necessary data for the analysis of vehicle operation till the date of $30^{\text {th }}$ 
December 2014 (Ježek, 2015) were obtained from this system. For subsequent evaluation, mainly due to the credibility and completeness of input data, traffic data only for the period from $1^{\text {st }}$ January 2010 are presented. At this time, the system was launched in a full operation (until the end of 2014).

\section{Evaluation of operational workload}

Tab. 3 summarizes the characteristics of the vehicle operation in terms of mileage and operating hours of machine work on the fire, accompanied by fuel consumed. All types of rides have been considered in total mileage of vehicles, i.e. to intervene, economic and training rides. For comparing with machine work in a stand, the mileage was converted per hours over an average speed of $50 \mathrm{~km} / \mathrm{h}$.

Then, average operating characteristics were calculated from obtained data. With this kind of technology, the machine work in a stand dominates; it represented $55 \%$ of total operating hours; even though the technology is also used to transport water to the place of intervention. The average annual mileage $2037 \mathrm{~km}$, however, does not indicate it. E.g. the first-response tankers on MAN chassis of the Fire and Rescue Service brigades in the South-Moravian Region have an average annual mileage $5200 \mathrm{~km}$.

In Fig. 1, there is the participation of monitored bulk tanks on TATRA chassis for managing incidents in the previous five years in the

Tab. 3 Overview of the monitored traffic technology for the years 2010 - 2014

\begin{tabular}{|c|c|c|c|c|c|c|c|}
\hline Fire station & License plate & $\begin{array}{c}\text { Mileage } \\
{[\mathrm{km}]}\end{array}$ & $\begin{array}{c}\text { Conversion } \\
\text { rides [h] }\end{array}$ & $\begin{array}{l}\text { The machine } \\
\text { work at the site } \\
\text { [h] }\end{array}$ & $\begin{array}{c}\text { Total } \\
\text { [h] }\end{array}$ & $\begin{array}{l}\text { Quantity } \\
\text { of fuel [l] }\end{array}$ & $\begin{array}{c}\text { Average fuel } \\
\text { consumption } \\
{[1 / 100 \mathrm{~km}]}\end{array}$ \\
\hline Blansko - VH_1 & BKA 15-02 & 7328 & 147 & 313 & 460 & 5718 & 78 \\
\hline Blansko - VH_2 & 9B1 3364 & 9142 & 183 & 105 & 288 & 5469 & 60 \\
\hline Boskovice - VH_1 & BKA 43-97 & 13438 & 269 & 356 & 625 & 9125 & 68 \\
\hline BVV - VH_1 & BKA 24-85 & 13617 & 272 & 311 & 583 & 8903 & 65 \\
\hline Líšeň - VH_1 & 5B4 3494 & 5066 & 101 & 89 & 191 & 3539 & 70 \\
\hline Lidická - VH_1 & BSB 63-63 & 14380 & 288 & 411 & 698 & 11084 & 77 \\
\hline Ivančice - VH_1 & BIA 07-26 & 10889 & 218 & 311 & 529 & 10772 & 99 \\
\hline Pohořelice - VH_1 & BVA 40-86 & 10825 & 217 & 151 & 367 & 6842 & 63 \\
\hline Pozořice - VH_1 & ZN 78-73 & 6967 & 139 & 335 & 474 & 9368 & 134 \\
\hline Rosice - VH_1 & BSD 46-43 & 16288 & 326 & 268 & 594 & 11955 & 73 \\
\hline Tišnov - VH_1 & BKA 26-39 & 7917 & 158 & 329 & 487 & 5855 & 74 \\
\hline Tišnov - VH_2 & 5B4 3306 & 18347 & 367 & 352 & 719 & 12487 & 68 \\
\hline Židlochovice - VH_1 & BSB 26-75 & 10090 & 202 & 287 & 489 & 6811 & 68 \\
\hline Břeclav - VH_1 & BVA 52-34 & 7477 & 150 & 183 & 333 & 5001 & 67 \\
\hline Mikulov - VH_1 & BSB 14-93 & 13638 & 273 & 314 & 587 & 8711 & 64 \\
\hline Hustopeče - VH_1 & BVA $35-40$ & 8377 & 168 & 225 & 393 & 5491 & 66 \\
\hline Hodonín - VH_1 & HO 87-65 & 7606 & 152 & 215 & 367 & 5333 & 70 \\
\hline Kyjov - VH_1 & 9B1 3370 & 7282 & 146 & 80 & 226 & 3835 & 53 \\
\hline Veselí n.M. - VH_1 & HOA 04-62 & 7638 & 153 & 219 & 372 & 5200 & 68 \\
\hline Bučovice - VH_1 & VY 76-33 & 6389 & 128 & 294 & 422 & 4859 & 76 \\
\hline Vyškov - VH_1 & VY 47-47 & 10564 & 211 & 217 & 428 & 7890 & 75 \\
\hline Hrušovany n.J. - VH_1 & ZN 63-75 & 8228 & 165 & 190 & 354 & 5618 & 68 \\
\hline Znojmo - VH_1 & ZN 82-04 & 11248 & 225 & 245 & 470 & 8997 & 80 \\
\hline Znojmo-VH_2 & 9B13362 & 9008 & 180 & 131 & 312 & 5403 & 60 \\
\hline \multicolumn{2}{|c|}{$\begin{array}{l}\text { Average annual mileage during the } \\
\text { reference period }\end{array}$} & 10073 & 201 & 247 & 449 & 7261 & 73 \\
\hline \multirow{2}{*}{\multicolumn{2}{|c|}{ Annual average per vehicle }} & 2037 & 41 & 49 & 90 & & \\
\hline & & $\begin{array}{c}\text { Quotient } \\
{[\%]}\end{array}$ & 45 & 55 & & & \\
\hline
\end{tabular}


South-Moravian Region documented. This is the result of processing and sorting rides on intervention rides and the others. The average share of rides to intervene was calculated at $49 \%$ of the total number of rides. The common share of rides to intervene of the first-response standard vehicles is to $2 / 3$ of the total number of rides.

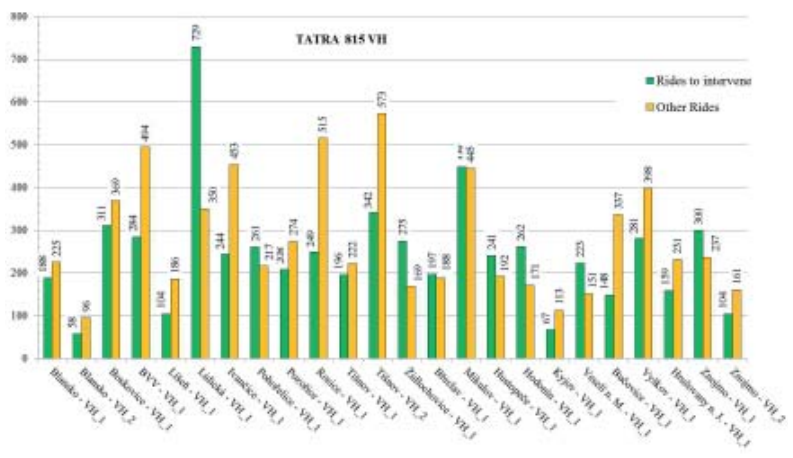

Fig. 1 Response activity of monitored firefighting equipment

\section{Evaluation of failure}

To evaluate the failure rate of the observed vehicles, the statistical data on maintenance and repairs were divided into groups:

- repairs after failure (in division of occurrence on chassis base and fire-bodywork),

- preventive maintenance (inspection, testing, scheduled inspections, state technical inspections, emissions),

- repairs after damage (during the intervention, after a traffic accident).

Fig. 2 summarizes the results of the primary analysis of service interventions in basic division into repairs after failure and preventive maintenance. The average number of repairs after failure was 18 faults per a vehicle during the monitored period. Repairs after damage were not observed.

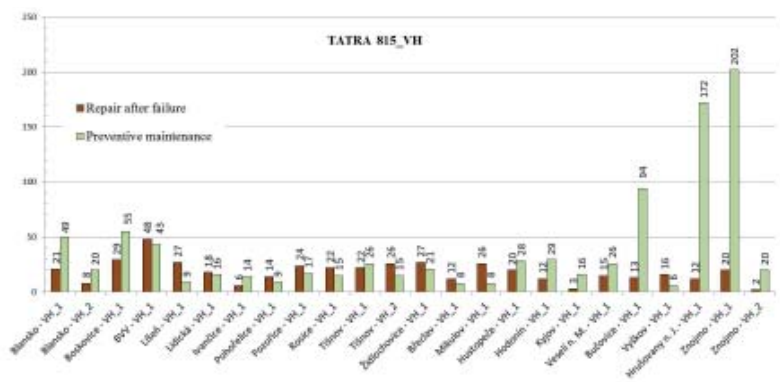

Fig. 2 Overview of service activities

At the stations in Hrušovany and Znojmo, there are not the preventative maintenance information for the years 2011 and 2012 clearly recorded in the system. Mechanic of machinery service, somehow accidentally, recorded so called "technical treatment" into the system several times and this mistake has not been removed later.

In Fig. 3, there are repairs after failure classified according to their occurrence on the chassis base and fire-bodywork. The graph shows the predominance of faults on the chassis. The vehicle age is noticeably reflected there. If we divide the total absolute number of repairs during the reporting period, we come to number 3 repairs a year after failure per a vehicle; which does not look so scary.

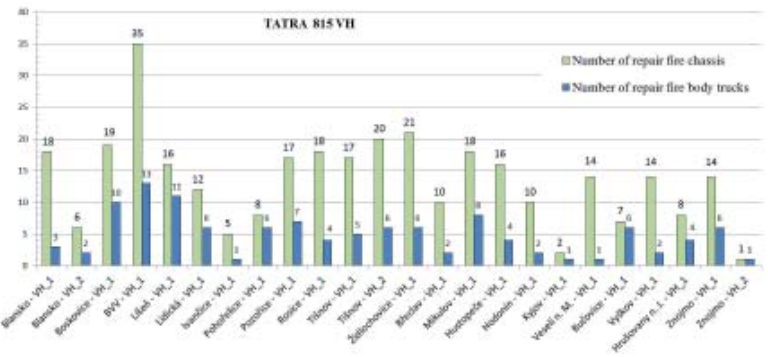

Fig. 3 Repairs division after failure

\section{Results}

The so-called "test plan" method was chosen for the calculation of operating characteristics (Famfulík, 2010). By this method, mean times to failure can be determined for a small group of products. The test is suitable for a limited number of products in advance. To evaluate failure, the test plan limited by time before failure has been chosen, it is co called " $t$ - plan". The duration of the test is the limit and the number of detected failures is a random variable. The assumption of the test is that the products are repaired after a failure. The accumulated working time of the vehicle $T_{A K U}$ is a time variable representing the course of the test. $T_{A K U}$ is the total time during which all products were in operation. The accumulated working time for the chosen $t$ - plan is calculated according to the following equation:

$$
T_{A K U}=\Sigma\left(\tau_{0}-\theta_{i}\right)+(n-r) \cdot \tau_{0}
$$

where:

$\tau_{0} \quad$ test time, from the beginning to the formation $r_{0}$ - the failure,

$n$ number of tested products,

$r \quad$ number of fault units,

$\theta_{i} \quad$ time needed to repair $i$ - product.

Time to failure was calculated at the monitored vehicles for the calculation of the operating characteristics with the " $t$ - plan" method. Due to 
availability and verifiability of the input data of the monitored vehicles, their operation was evaluated from $1^{\text {st }}$ January 2010 to $31^{\text {st }}$ December 2014. Considering the accuracy of the data, only mileage of vehicles and mileage at the time of the disturbance was taken into account when calculating. Limit test time $\tau_{0}$ was set for 2500, 5000 a $7500 \mathrm{~km}$ limits. These limits were subsequently converted into time by dividing the mileage by average speed of $50 \mathrm{kph}$; with this value FRS CR usually works. Than, the calculation was made according to the equation (1) and calculated accumulated time was then converted back to kilometers. The results of the calculations showed that failure occurs on the vehicle before reaching the limit value of kilometric mileage. The calculation results of times to failure depending on the limit test period are recorded in the graph in Fig. 4.

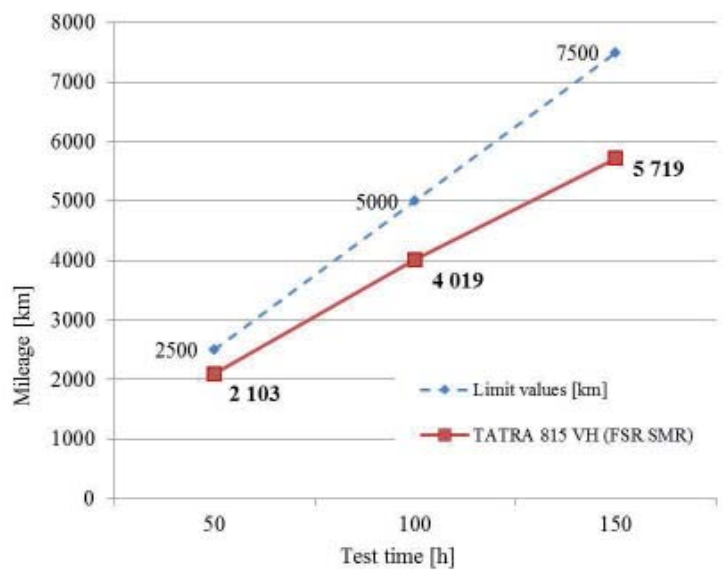

Fig. 4 Results for calculating the accumulated working time

Further, (according to Stodola, 2002) for the monitored bulk tank calculation, availability coefficient $K_{p}$ was determined by calculation of the equation:

$$
K_{P}=\frac{\sum_{j=1}^{n} t_{p j}}{\sum_{j=1}^{n} t_{p j}+\sum_{i=1}^{n} t_{o i}}
$$

where:

$\sum t_{p j}$ the sum of times of failure-free operation,

$\sum t_{o i}$ the sum of service time during the period under review.

Equation (2) can be adjusted on the basis of previously used symbols in shape:

$$
K_{p}=\frac{T_{A K U}}{T_{A K U}+\sum_{i=1}^{n} \theta_{i}}
$$

The calculation results are shown in Fig. 5 for defined time intervals of testing. The graph shows a decreasing trend of this factor. Its low value in the test of interval of 50 hours is even more serious. These hours after conversion represent mileage $2500 \mathrm{~km}$. If we convert the coefficient $K_{p}=0.841$ back into time of repair and we generally substitute $T_{A K U}=100 \%$, it turns out that we need to spend $19 \%$ extra time on repairs after failure to obtain such value. This share is still increasing at $31 \%$ of the time for repairs for the largest interval of test time.

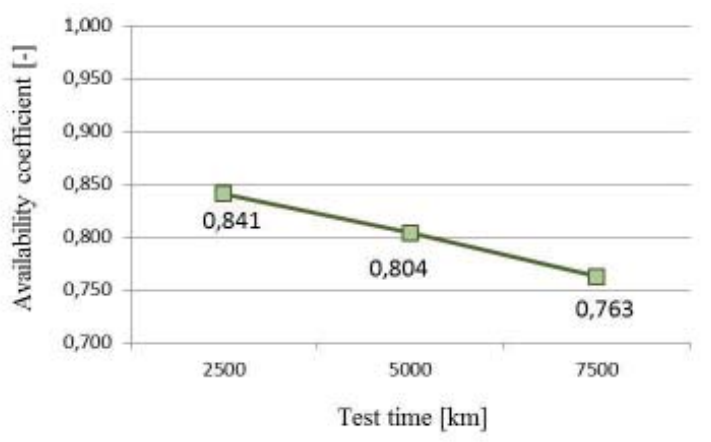

Fig. 5 Availability coefficient of monitored bulk tanks

\section{Discussion}

We can deduce some direct conclusions from the demonstrable results of previous research (Jánošík, 2014a) a (Jánošík, 2014b) which was focused mainly on the first-response tanks. The most important of them is the fact that when evaluating the reliability of general, it is appropriate to characterize the operation of fire fighting equipment with longer mileage than usual, in the literature cited, $1000 \mathrm{~km}$ mileage. It has been declared also on other characteristics of reliability the results change when longer time intervals monitoring. Therefore, it was used a longer period than in previous research. The initial test interval of 50 hours was set for bulk tanks. These hours represent mileage $2500 \mathrm{~km}$ after conversion. This is the value that 15 monitored vehicles do not pass trough a year. A longer time interval of the test also ensures that different climatic conditions were carried during operation of this technique.

\section{Conclusion}

An imaginary winner among monitored first line technique on MAN TGM, Renault Midlum, Mercedes-Benz Atego, Mercedes-Benz Econic and TATRA chassis in the time period 2010 - 2013 were CAS vehicles, of first and second response, on the chassis TATRA 815-2 TerrNo1 in the SouthMoravian Region. The same chassis of bulk tanks 
has not reached so good results. Fig. 6 shows a comparison of the summary results of calculations of the accumulated time of previously monitored vehicles. You can make a comparison of average values of kilometric mileage by approximation between the intervals 40 and 60 hours. For example MB Econic, that as a design prototype is a "weakest" vehicle from the monitored group in terms of reliability, reaches the average of up to $2141 \mathrm{~km}$ at the time of testing 50 hours, while bulk tank chassis TATRA only $2103 \mathrm{~km}$. Winning first-response Tatras vehicles achieved the value of $2484 \mathrm{~km}$. These established facts appear to be a good reason to think about the renewal of certain vehicles from the oldest age group, where the average age is of 27.5 years. As can be seen from Tab. 1, the replacement of these tanks has been carried out in recent years, at least the cheaper option of reconstruction of the vehicle. But only six vehicles of these renovated tanks, which were reconstructed after 2008, still meet our technical requirements for fire equipment.

\section{Acknowledgments}

This paper was supported by an internal grant of specific research "SP2014/44 - Determining aspects of operational and functional reliability of fire-fighting equipment."

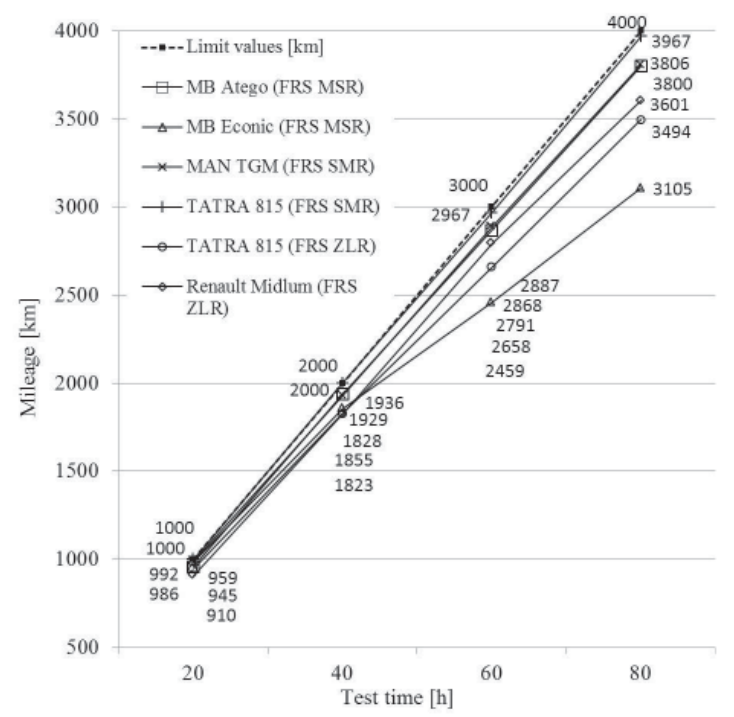

Fig. 6 Summary results of calculations of accumulated working time

\section{References}

FAMFULIK, J., KRZYZANEK R., GALVAS, P. (2010). Reliability Tests: Selected Stochastic Methods - $1^{\text {st }}$ ed., Ostrava: VSB - Technical University of Ostrava, 2010, 67 p. ISBN 978-80-248-2277-8. (in Czech)

JANOSIK, L. (2014). The functional reliability of fire fighting equipment on Tatra 815 chassis in units of FRS South Moravia and Zlín Region. In Advances in Fire and Safety Engineering: Trnava. [CD-ROM] Trnava: AlumniPress, 2014, pp. 132-137. ISBN 978-80-8096-202-9. (in Slovak)

JANOSIK, L.(2014). Evaluation of the operation of fire fighting equipment on the chassis of Tatra 815 in units of FRS CR South Moravia and Zlín Region. In ICMT 2014: International Conference on Military Technologies and Special Technologies 2014. Bratislava, 14 ${ }^{\text {th }}$ May 2014: proceedings of reviewed papers. [CD-ROM] Trencin: University of Alexander Dubcek in Trencin, 2014. pp. 104-112, ISBN 978-80-8075-639-0.

JEZEK, B. (2015). Personal consultation and export operation data from IKIS II. FRS South Moravian region. Regional Directorate of Brno, Department IRS and services Zubatého 1, $6^{\text {th }}$ January 2015.

MONOSI, M et al. (2013). Fire-fighting equipment. University textbooks. $1^{\text {st }}$ edition, Zilina: EDIS, University in Zilina, 2013. 402 p. ISBN 978-80-554-0705-0.

Instruction No. 9 (2006). Instructions No. 9 of General Director of Fire Rescue Service and the Deputy of Ministry of Interior dated 13 ${ }^{\text {th }}$ March 2006 issued Order of Mechanical Services Fire Rescue Service of the Czech Republic.

STODOLA, J.(2002). Operational Reliability and Diagnostics (in Slovak), Brno: University of Defence, 2002. 88 p. ISBN 80-85960-43-5.

THT (2015). Fire equipment [online]. Policka: THT Ltd. [cit. 2015-02-15]. Available at: http://www.tht.cz/cs/ pozarni-technika.

VONASEK, V. et al. (2010 till 2014). Statistical annual of the Fire and Rescue Service for the years 2010 to 2014 [online]. Prague: Ministry of Interior - General Directorate of Fire Rescue Service of the Czech Republic [cit. 2015-03-20]. Available at: http://www.hzscr.cz/clanek/statisticke-rocenky-hasicskeho-zachrannehosboru-cr.aspx. 